\title{
Gestalt Counseling with Dialog Game Techniques and Hipno Counseling Techniques for Self Achievement
}

\author{
Konseling Gestalt dengan Teknik Permainan Dialog dan Teknik Hipnokonseling terhadap Self \\ Achievement
}

\author{
Wayan Eka Paramartha ${ }^{1}$, I Ketut Dharsana ${ }^{2}$, Ni Ketut Suarni ${ }^{3}$ \\ ${ }^{123}$ Universitas Pendidikan Ganesha \\ e-mail: eka.paramartha@pasca.undiksha.ac.id
}

Received January 23, 2017

Revised March 16, 2017

Accepted Mei 30, 2017

Published Online June 30, 2017

\section{Conflict of Interest}

Disclosures:

The authors declare that they have no significant competing financial, professional or personal interests that might have influenced the performance or presentation of the work described in this manuscript.

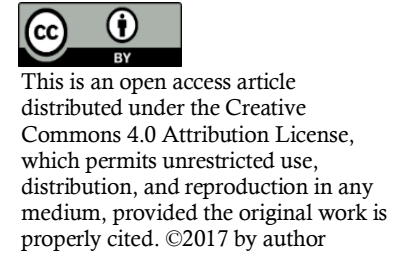
properly cited. C2017 by author

\begin{abstract}
The purpose of this research is to know the influence between gestalt counseling with techniques of game dialogue and hipnocounseling technique against self achievement in terms of the gender of the student. The research is the research experiments with $2 \times 2$ factorial design, this research was conducted in SMA Negeri 1 Sukasada. The Sampling technique used to determine the research sample is Random sampling. Data collection methods used are observation, interview, questionnaire and diary, recording documents. Data research results are analyzed using two lines of Anova. The results showed that, there may be differences between the influence of gestalt counseling with techniques of game dialogue and hipnocounseling technique against self achievement.
\end{abstract}

Keywords: gestalt, the game's dialogue, hipnocounseling, self achievement, gender

\begin{abstract}
Abstrak: Tujuan penelitian ini adalah untuk mengetahui pengaruh antara konseling gestalt dengan teknik permainan dialog dan teknik hipnokonseling terhadap self achievement ditinjau dari jenis kelamin siswa. Penelitian ini adalah penelitian eksperimen dengan desain faktorial 2x2, Penelitian ini dilakukan di SMA Negeri 1 Sukasada. Teknik Sampling yang digunakan untuk menentukan sampel penelitian adalah Random sampling. Metode pengumpulan data yang digunakan adalah observasi, wawancara, buku harian, kuesioner dan pencatatan dokumen. Data hasil penelitian dianalisis menggunakan Anava dua jalur. Hasil penelitian menunjukkan bahwa, terdapat perbedaan pengaruh antara konseling gestalt dengan teknik permainan dialog dan teknik hipnokonseling terhadap self achievement
\end{abstract}

Kata Kunci: gestalt, permainan dialog, hipnokonseling, self achievement, jenis kelamin

How to Cite: Paramartha, W. E., Dharsana, I. K., \& Suarni, N. K. (2017). Gestalt Counseling with Dialog Game Techniques and Hipno Counseling Techniques for Self Achievement. Bisma, 1(1), 39-49. https://doi.org/10.23887/128322017

\section{Pendahuluan}

Bimbingan dan konseling merupakan suatu kegiatan layanan yang diberikan oleh seorang Guru BK atau konselor sekolah untuk mengembangkan potensi serta aspek-aspek perkembangan yang dimiliki oleh individu sehingga dapat dikatakan peran Bimbingan Konseling sangat penting dalam pengembangan mutu 
serta kualitas sebuah sekolah. Jika kita lihat dari masyarakat pada umumnya sebuah sekolah atau lembaga pendidikan secara umum dapat dikatakan berkualitas dengan cara melihat output yang dihasilkan oleh sebuah sekolah, dalam kata lain masyarakat akan menganggap sebuah sekolah itu berkualitas apabila siswa atau peserta didik yang dihasilkan memiliki kualitas yang sesuai dengan harapan/ keinginan masyarakat. Dalam proses pembelajaran di sekolah tidak jarang banyak permasalahan yang sering dihadapi oleh siswa. Salah satunya adalah kurangnya motivasi belajar dan kurangnya dorongan untuk berprestasi dan lebih unggul dari orang lain. Hasil dari pengamatan serta wawancara yang dilakukan di kelas X SMA Negeri 1 Sukasada, menunjukkan bahwa terdapat sebagian siswa yang menunjukkan gejala-gejala seperti menyelesaikan sesuatu dengan ceroboh dengan hasil yang kurang memuaskan, membiarkan tugas-tugas yang diberikan dan tanpa adanya niat serta usaha untuk menyelesaikannya, menghindari masalah, kurang memiliki dorongan untuk melakukan sesuatu yang lebih baik dari orang lain. Terdapat juga sebagian siswa yang menunjukkan gejala seperti dapat menyelesaikan sesuatu dengan baik dan berhasil, menyelesaikan tugas dan memerlukan usaha diikuti keahlian dan keterampilan, memecahkan masalah yang sulit, mampu melakukan sesuatu yang lebih baik dari orang lain. Berdasarkan gejala yang ditunjukan oleh siswa di atas, maka siswa tersebut dapat dikatakan menunjukkan gejala self achievement.

Hasil pengamatan awal menunjukkan bahwa gejala-gejala perilaku self achievement berbeda antara siswa laki-laki dan siswa perempuan. Berdasarkan penelitian Kaufmann dan Richardson (dalam Matlin, 1987), ada dua gagasan mengenai self achievement pada wanita, yang pertama adalah bahwa wanita mungkin tidak terlalu termotivasi untuk berprestasi seperti pria. Yang kedua bahwa wanita lebih berusaha untuk mencegah agar tidak sukses karena beranggapan bahwa sukses itu akan mendatangkan ketidakbahagiaan. Kesuksesan memiliki unsur maskulin, seperti jabatan yang prestise, prestasi yang tinggi dan pencapaian lain yang berhubungan dengan nilai-nilai tradisional tentang maskulinitas.

Lesson study dalam bahasa Jepang disebut jugyokenkyu adalah bentuk kegiatan yang di lakukan oleh guru / sekelompok guru yang bekerjasama dengan orang lain (dosen, guru mata pelajaran yang sama, guru satu tingkat kelas yang sama, atau guru lainnya) merancang kegiatan untuk meningkatkan mutu belajar siswa dari pembelajaran yang dilakukan oleh salah seorang guru dari perencanaan pembelajaran yang dirancang bersama/sendiri, kemudian diobservasi oleh teman guru yang lain dan setelah itu mereka melakukan refleksi bersama atas hasil pengamatan pembelajaran yang baru saja dilakukan (Dharsana, 2016).

Berdasarkan latar belakang, maka dapat dikemukakan rumusan masalah sebagai berikut: 1) Apakah terdapat perbedaan self achievement antara siswa yang mengikuti konseling Gestalt dengan teknik permainan dialog dengan yang mengikuti teknik hipnokonseling? 2) Apakah terdapat perbedaan self achievement ditinjau dari perbedaan jenis kelamin? 3) Apakah terdapat pengaruh interaksi implementasi konseling Gestalt dengan jenis kelamin terhadap self achievement siswa. 4) Pada siswa yang berjenis kelamin laki-laki, apakah terdapat perbedaan self achievement antara siswa yang mengikuti konseling Gestalt dengan teknik permainan dialog dengan yang mengikuti teknik hipnokonseling? 5) Pada siswa yang berjenis kelamin perempuan, apakah terdapat perbedaan self achievement antara siswa yang mengikuti konseling Gestalt dengan teknik permainan dialog dengan yang mengikuti teknik hipnokonseling? 6) Pada siswa yang mengikuti konseling Gestalt teknik permainan dialog, apakah terdapat perbedaan self achievement ditinjau dari jenis kelamin? 7) Pada siswa yang mengikuti konseling Gestalt teknik hipnokonseling, apakah terdapat perbedaan self achievement ditinjau dari jenis kelamin?

Penelitian ini bertujuan untuk mengetahui dan menganalisis pengaruh konseling Gestalt dengan teknik permainan dialog dan teknik hipnokonseling terhadap self achievement ditinjau dari perbedaan jenis kelamin siswa

\section{Self Achievement}

Menurut (Dharsana 2009:2) "Achievement adalah kebutuhan untuk berprestasi", meliputi menyelesaikan sesuatu dengan baik dan akan berhasil, menyelesaikan tugas dan memerlukan usaha diikuti keahlian dan keterampilan, menyelesaikan sesuatu yang penting sekali artinya, melaksanakan suatu pekerjaan yang sulit, memecahkan masalah yang sulit, akan mampu melakukan sesuatu yang lebih baik dari orang lain, menulis suatu drama, novel yang termasyur.

Selanjutnya, menurut McClelland (dalam Suarni, 2004:28), "Need of Achievement adalah suatu usaha untuk mencapai hasil yang sebaik-baiknya berdasarkan standar keunggulan. Sejalan dengan pendapat di atas, Murray (dalam Dharsana, 2010) mengatakan, "Achievement merupakan sebuah kebutuhan untuk 
menyelesaikan sesuatu yang sulit dan menarik, menguasai, mengatasi rintangan dan mencapai standar berbuat sebaik mungkin dan bersaing mengungguli orang lain". Kemudian menurut Fatchurrohman, (2017). Motivasi berprestasi adalah kesungguhan atau daya dorong seseorang untuk berbuat lebih baik dari apa yang pernah dibuat atau diraih sebelumnya maupun yang dibuat atau diraih orang lain. McClelland (1953) defined the achievement motive as "competing with a standard of excellence. "Mendefinisikan motif berprestasi sebagai bersaing dengan standar keunggulan" (Gruber, 2017).

Berdasarkan atas pemaparan definisi tersebut, maka dalam penelitian ini yang dimaksud dengan Self Achievement adalah kebutuhan untuk berprestasi", meliputi menyelesaikan sesuatu dengan baik dan akan berhasil, menyelesaikan tugas dan memerlukan usaha diikuti keahlian dan keterampilan, menyelesaikan sesuatu yang penting sekali artinya, melaksanakan suatu pekerjaan yang sulit, memecahkan masalah yang sulit, akan mampu melakukan sesuatu yang lebih baik dari orang lain, menulis suatu drama, novel yang termasyur. Berdasarkan pendapat tersebut di atas mengisyaratkan bahwa indikator Self Achievement sebagai berikut: 1) menyelesaikan sesuatu dengan baik dan akan berhasil, 2) menyelesaikan tugas dan memerlukan usaha diikuti keahlian dan keterampilan, 3) memecahkan masalah yang sulit, 4) mampu melakukan sesuatu yang lebih baik dari orang lain.

\section{Teori Konseling Gestalt}

Teori konseling Gestalt merupakan proses treatmen yang memandang bahwa individu memiliki kesanggupan memikul tanggung jawab pribadi dan hidup sepenuhnya sebagai pribadi yang terpadu, dan sasaran konseling Gestalt adalah pemulihan kesadaran serta pada pemaduan polaritas-polaritas dan dikotomi-dikotomi dalam diri sehingga self achievement siswat dapat ditingkatkan dan diterapkan dalam bidang pribadi, sosial, belajar dan karir (Dharsana, 2015).

Gestalt therapy is a holistic, process-oriented, dialogical, phenomenological, existential, and field theoretical approach to human change with the centrality of contact, awareness, and personal responsiveness and responsibility. Primacy is given to the uniqueness of the individual. The person is never reduced to parts and structural entities but viewed as an integrated whole with innate potential of growth and mature self-expression. "Konseling Gestalt adalah pendekatan holistik, berorientasi pada proses, dialogis, fenomenologis, eksistensial, dan teoritis bidang terhadap perubahan manusia dengan sentralitas kontak, kesadaran, dan responsif dan tanggung jawab pribadi. Keistimewaan diberikan pada keunikan individu. Orang tersebut tidak pernah terpuruk menjadi bagian dan entitas struktural namun dipandang utuh secara keseluruhan dengan potensi pertumbuhan dan ekspresi diri yang matang". (Kirchner, (2000). Teori Konseling Gestalt memiliki beberapa teknik diantaranya yaitu: teknik permainan dialog, teknik pembalikan, teknik berkeliling, teknik bertanggung jawab atas, teknik melebih-lebihkan dan teknik hipno konseling. Gejala self achievement tersebut dapat meningkat mana kala disentuh atau ditreatmen dengan cara atau teknik yang selaras atau berbeda dengan teori konseling. Teknik yang dianggap mampu untuk meningkatkan self achievement yaitu teknik permainan dialog dan teknik hipnokonseling.

Teknik permainan dialog adalah suatu cara untuk mengajak konseli untuk mengeksternalisasikan introyeksinya. Teknik ini membantu konseli agar bisa berhubungan dengan perasaan atau sisi dari dirinya sendiri yang diingkarinya, konseli mengintensifkan dan mengalami secara penuh perasaan-perasaan yang bertentangan, ketimbang hanya membicarakannya, sehingga konseli mampu mengembangkan self achievementnya (Dharsana, 2014).

Hipnokonseling adalah suatu cara yang diberikan oleh konselor dengan jalan membimbing konseli menuju alam bawah sadar dalam membantu untuk membentuk, mempertahankan dan meningkatkan perilaku yang diinginkan. Teknik Hipnokonseling mengandung langkah-langkah sebagai berikut: 1) Pre induksi yaitu melakukan rapport dengan siswa, 2) Induksi yaitu proses pergeseran perhatian atau proses by pass critical factor, 3) Deepening yaitu menghantarkan siswa ke kedalaman trans yang lebih dalam, 4) Treatmen yaitu pemberian sugesti/healing, 5) Terminasi yaitu membawa kembali pada kondisi normal dan terjaga. (Dharsana, 2013)

\section{Metode}

Penelitian ini merupakan penelitian quasi eksperimen yang sering juga disebut penelitian eksperimen semu. Menurut Dantes (2012:95), penelitian quasi eksperiment merupakan metode eksperimen yang dilakukan seolah-olah seperti penelitian eksperimen sebenarnya". Penelitian ini menggunakan rancangan 
penelitian Two Factor Design atau sering disebut desain faktorial $2 \times 2$. Dalam desain ini terdapat tiga variabel yang terdiri dari variabel bebas, variabel moderator, variabel terikat. Variabel bebas adalah konseling Gestalt dengan teknik Permainan dialog dan Hipnokonseling (A) sebagai variabel perlakuan, variabel moderator adalah ditinjau dari jenis kelamin (B), variabel terikat adalah Self Achievement (Y). Penelitian ini menggunakan teknik random sampling dan random class sebagai intact group. Adapun yang dimaksud dengan random sampling yaitu pengambilan sampel anggota populasi dilakukan dengan memilih sample secara acak, tanpa memperhatikan strata yang ada dalam populasi itu. Semua objek disuatu kelas tersebut dianggap memiliki kesempatan yang sama untuk diambil sebagai sampel (Dantes, 2012).

Penelitian ini menggunakan kuesioner sebagai metode pengumpulan data utama. Kemudian dengan metode observasi, wawncara dan buku harian. Dalam penelitian ini variabel yang diukur adalah Self Achievement, serta penyusunan instrumen angket dalam penelitian ini adalah skala Likert. Validitas isi mengenai kuesioner Self Achievement siswa dihitung dengan formula Gregory. Hasil perhitungan validitas isi kuesioner Self Achievement yang telah ditelaah, menunjukan koefisien validitas isi adalah 1. Jadi butir tes memiliki Validitas Isi (Content Validity) sangat tinggi. Berdasarkan uji validitas yang dilakukan terhadap 30 butir soal kuesioner self achievement, koefisien rhitung bergerak dari 0,310 sampai 0,747. Setelah dikonsultasikan dengan rtabel pada $\mathrm{df}=93$ dengan taraf siginifikansi $5 \%$ yaitu 0,202 menunjukkan rhitung > rtabel sehingga tidak ditemukan butir soal yang gugur, hal ini berarti seluruh butir soal dinyatakan valid, maka dari itu jumlah butir soal kuesioner self achievement adalah sebanyak 30 butir. Kemudian hasil perhitungan koefisien reliabilitas dengan menggunakan Alpha Cronbach, perbandingan ralpha dengan rtabel menunjukkan ralpha yaitu 0,927 sedangkan rtabel yaitu $\mathrm{df}=95-2=93$ dengan taraf siginifikansi 5\% yaitu 0,202 sehingga menunjukkan, ralpha > rtabel 0,927>0,202, maka dapat disimpulkan bahwa butir instrumen yang digunakan reliabel atau Derajat Reliabilitas Sangat Tinggi berdasarkan klasifikasi Guilford, sehingga intstrumen kuesioner self achievement ini layak untuk digunakan dalam penelitian. Data Self Achievement akan dianalisis dengan statistik deskripif yang penyimpulannya didasarkan atas skor rerata dan simpangan baku.

Uji normalitas data dalam penelitian ini menggunakan statistik Kolmogorov-smirnov yang dikenakan pada delapan kelompok data. Penghitungan dengan statistik Kolmogorov smirnov menunjukkan bahwa nilai signifikansi (p) lebih besar dari 0.05 untuk semua kelompok.

Homogenitas varians diuji dengan menggunakan Levene's Test of Equality of Error Variance. Nilai signifikansi 0,568. Apabila ditetapkan taraf signifikansi 5\%, maka nilai ini lebih besar dari 0,05 ini berarti nilai 0,568>0,05. Dengan demikian dapat dikatakan bahwa varians data self achievement antara kelompok yang diberikan layanan konseling gestalt dengan teknik permainan dialog dan kelompok yang diberikan layanan teknik hipnokonseling dan jenis kelamin adalah sama atau homogen.

Teknik analisis yang digunakan untuk pengujian hipotesis dalam penelitian ini adalah teknik analisis varians (ANAVA) dua jalan. 
Tabel 01 Hasil Tes Anava Dua Jalur dan Analisis Deskriptif

\section{Tests of Between-Subjects Effects}

Dependent Variable: Self Achievement

\begin{tabular}{lrrccc}
\hline Source & $\begin{array}{c}\text { Type III Sum of } \\
\text { Squares }\end{array}$ & Df & Mean Square & F & Sig. \\
\hline Corrected Model & $664.787^{\mathrm{a}}$ & 5 & 132.957 & 1.995 & .092 \\
\hline Intercept & 812615.414 & 1 & 812615.414 & 12190.846 & .000 \\
\hline Teknik & 593.162 & 2 & 296.581 & 4.449 & .016 \\
\hline Jenis Kelamin & 5.232 & 1 & 5.232 & .078 & .780 \\
\hline Teknik Jenis Kelamin & 21.707 & 2 & 10.854 & .163 & .850 \\
\hline Error & 3999.470 & 60 & 66.658 & & \\
\hline Total & 845837.000 & 66 & & & \\
\hline Corrected Total & 4664.258 & 65 & & & \\
\hline
\end{tabular}

a. R Squared $=.143$ (Adjusted R Squared $=.071)$

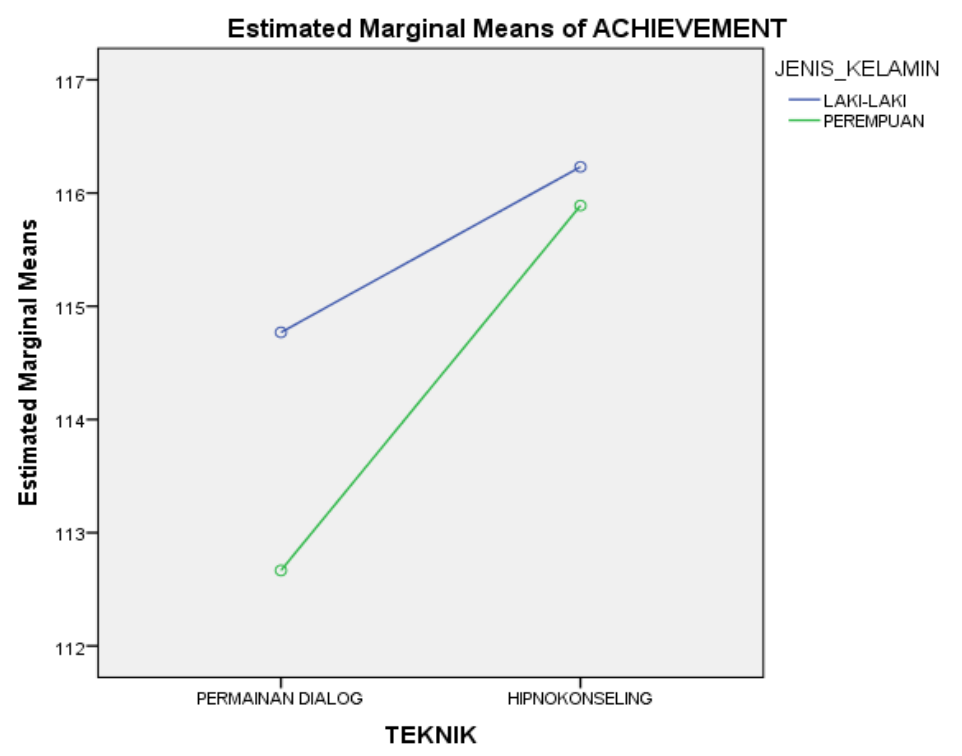

Gambar 1. Plots of Estimated Marginal Means of Self Achievement

Hipotesis pertama, berbunyi: Terdapat perbedaan self achievement antara siswa yang mengikuti konseling Gestalt teknik permainan dialog dengan yang mengikuti teknik hipnokonseling. Kriteria penolakan Ho apabila antar tingkatan teknik nilai Fhitung lebih besar daripada nilai Ftabel (Fh $>$ Ft) atau angka signifikansi lebih kecil dari $0,05 /(\mathrm{p})<0,05$. Berdasarkan nilai signifikansi yang diperoleh yaitu 0,016 ini berarti $0,016<0,05$ maka dapat disimpulkan bahwa hipotesis nol yang menyatakan "tidak terdapat perbedaan self achievement antara siswa yang mengikuti konseling Gestalt dengan teknik permainan dialog dengan yang mengikuti teknik hipnokonseling", ditolak. Sebaliknya hipotesis alternatif 
(H1) yang menyatakan bahwa "terdapat perbedaan self achievement antara siswa yang mengikuti konseling Gestalt dengan teknik permainan dialog dengan yang mengikuti teknik hipnokonseling", diterima.

Hipotesis kedua berbunyi: Terdapat perbedaan self achievement ditinjau dari perbedaan jenis kelamin. Kriteria penolakan Ho apabila antar tingkatan jenis kelamin (antar kolom) nilai Fhitung lebih besar daripada nilai Ftabel $(\mathrm{Fh}>\mathrm{Ft})$ atau angka signifikansi lebih kecil dari 0,05/ (p) $<0,05$. Berdasarkan nilai signifikansi yang didapatkan sebesar 0.780 ini berarti nilai signifikansi (p) lebih besar dari 0,05 atau $0,780>0,05$, maka dapat disimpulkan bahwa hipotesis nol yang menyatakan "tidak terdapat perbedaan self achievement ditinjau dari jenis kelamin", diterima.

Hipoteisi ketiga berbunyi: Terdapat pengaruh interaksi implementasi konseling Gestalt dengan jenis kelamin terhadap self achievement siswa. Kriteria penolakan Ho apabila antar tingkatan faktor pada interaksi teknik dengan jenis kelamin (antar kolom) nilai Fhitung lebih besar daripada nilai Ftabel (Fh $>$ Ft) atau angka signifikansi lebih kecil dari 0,05. Berdasarkan nilai signifikansi didapatkan pada Corrected Model yaitu pengaruh semua variabel independen dan interaksi teknik dengan jenis kelamin secara bersama-sama terhadap variabel dependen sebesar 0.092 ini berarti nilai signifikansi lebih besar dari 0,05 atau 0,092>0,05, maka dapat disimpulkan bahwa hipotesis nol yang menyatakan "tidak terdapat pengaruh interaksi konseling gestalt teknik permainan dialog dan teknik hipnokonseling dengan jenis kelamin terhadap self achievement", diterima.

Hipotesis Keempat berbunyi: Terdapat perbedaan self achievement antara siswa yang mengikuti konseling Gestalt dengan teknik permainan dialog dengan yang mengikuti teknik hipnokonseling pada siswa yang berjenis kelamin laki-laki. Hasil self achievement dikatakan berbeda secara signifikan jika (p) $<0,05$ pada taraf signifikansi 5\% atau menolak H0 jika, sebaliknya terima H0 jika (p) $>0,05$ pada taraf signifikansi 5\%. Hasil uji Tukey diperoleh nilai Sig. sebesar 0,902, maka dapat disimpulkan bahwa hipotesis nol yang menyatakan "Tidak terdapat perbedaan self achievement antara siswa yang mengikuti konseling gestalt dengan teknik permainan dialog dengan yang mengikuti teknik hipnokonseling pada siswa yang berjenis kelamin laki-laki", diterima.

Hipotesis kelima berbunyi: Terdapat perbedaan self achievement antara siswa yang mengikuti konseling Gestalt dengan teknik permainan dialog dengan yang mengikuti teknik hipnokonseling pada siswa yang berjenis kelamin perempuan. Hasil uji Tukey diperoleh nilai Sig. sebesar 0,633 ini berarti (p) >0,05, maka dapat disimpulkan bahwa hipotesis nol yang menyatakan "Tidak terdapat perbedaan self achievement antara siswa yang mengikuti konseling gestalt dengan teknik permainan dialog dengan yang mengikuti teknik hipnokonseling pada siswa yang berjenis kelamin perempuan", diterima.

Hipotesis keenam berbunyi: Terdapat perbedaan self achievement pada siswa yang mengikuti konseling Gestalt teknik permainan dialog ditinjau dari jenis kelamin. Berdasarkan uji Independent Samples Test di atas diperoleh nilai Sig. (2-tailed) sebesar 0,457 sehingga 0,457>0,05 maka dapat disimpulkan bahwa hipotesis nol yang menyatakan "Tidak terdapat perbedaan self achievement antara siswa yang mengikuti konseling gestalt dengan teknik permainan dialog ditinjau dari jenis kelamin, diterima.

Hipotesis ketujuh berbunyi: Terdapat perbedaan self achievement pada siswa yang mengikuti konseling Gestalt teknik hipnokonseling ditinjau dari jenis kelamin. Berdasarkan uji Independent Samples Test di atas diperoleh nilai Sig. (2-tailed) sebesar 0,901 sehingga 0,901>0,05, maka dapat disimpulkan bahwa hipotesis nol yang menyatakan "Tidak terdapat perbedaan self achievement antara siswa yang mengikuti konseling gestalt dengan teknik hipnokonseling ditinjau dari jenis kelamin, diterima.

\section{Hasil dan Pembahasan}

Temuan empiris pada penelitian ini menyatakan bahwa terdapat perbedaan pengaruh konseling gestalt antara teknik permainan dialog dengan teknik hipnokonseling terhadap self achievement. Rata-rata Self achievement kelompok siswa yang mengikuti teknik hipnokonseling lebih tinggi jika dibandingkan dengan kelompok siswa yang mengikuti teknik permainan dialog. Hal ini mengindikasikan bahwa konseling gestalt akan lebih efektif jika konseli dalam pelaksanaan konseling difasilitasi dengan teknik hipnokonseling. 


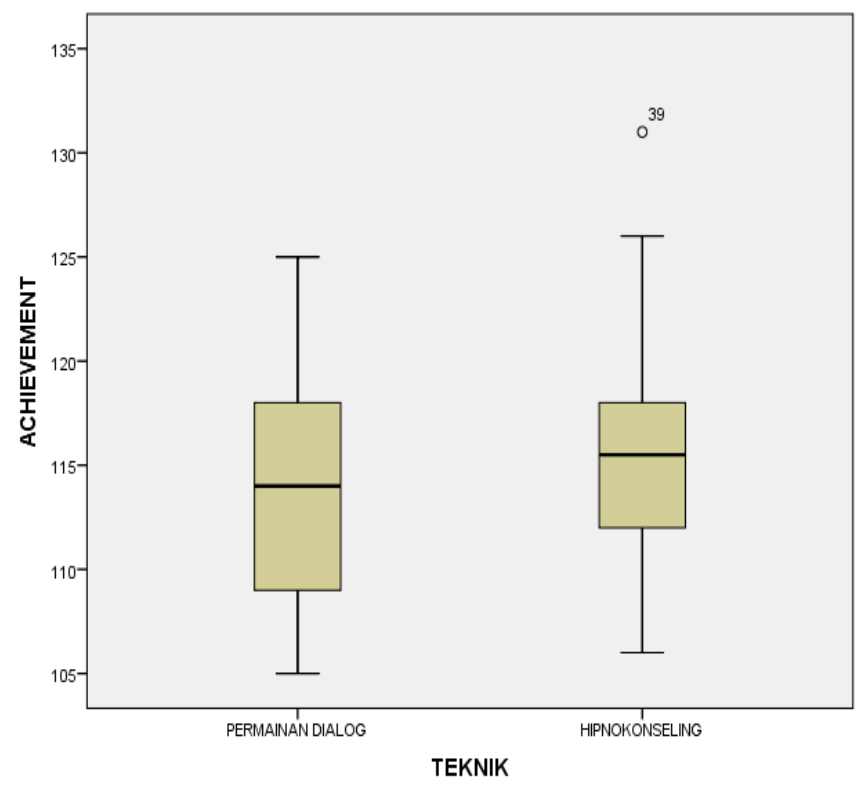

Gambar 2. Boxplots of Teknik Konseling

Tabel 01. Hasil Perhitungan Ukuran Tendensi Sentral dan Ukuran Penyebaran Data Self achievement

\begin{tabular}{|c|c|c|c|}
\hline \multicolumn{4}{|c|}{ Dependent Variable: Self Achievement } \\
\hline Teknik & Jenis_Kelamin & Mean & Std. Deviation \\
\hline \multirow[t]{3}{*}{ Permainan Dialog } & Laki-Laki & 114.77 & 6.930 \\
\hline & Perempuan & 112.67 & 5.477 \\
\hline & Total & 113.91 & 6.324 \\
\hline \multirow[t]{3}{*}{ Hipnokonseling } & Laki-Laki & 116.23 & 7.236 \\
\hline & Perempuan & 115.89 & 4.428 \\
\hline & Total & 116.09 & 6.117 \\
\hline \multirow[t]{3}{*}{ Total } & Laki-Laki & 115.50 & 6.981 \\
\hline & Perempuan & 114.28 & 5.108 \\
\hline & Total & 115.00 & 6.247 \\
\hline
\end{tabular}

Temuan berikutnya menyatakan bahwa tidak terdapat perbedaan self achievement ditinjau dari jenis kelamin. Hasil ini dibuktikan dengan nilai signifikansi yang didapatkan sebesar 0.780 . Hal ini mengindikasikan bahwa jenis kelamin tidak mempengaruhi self achievement siswa. Antara siswa laki-laki dan siswa perempuan tidak ditemukan perbedaan self achievement secara signifikan. 


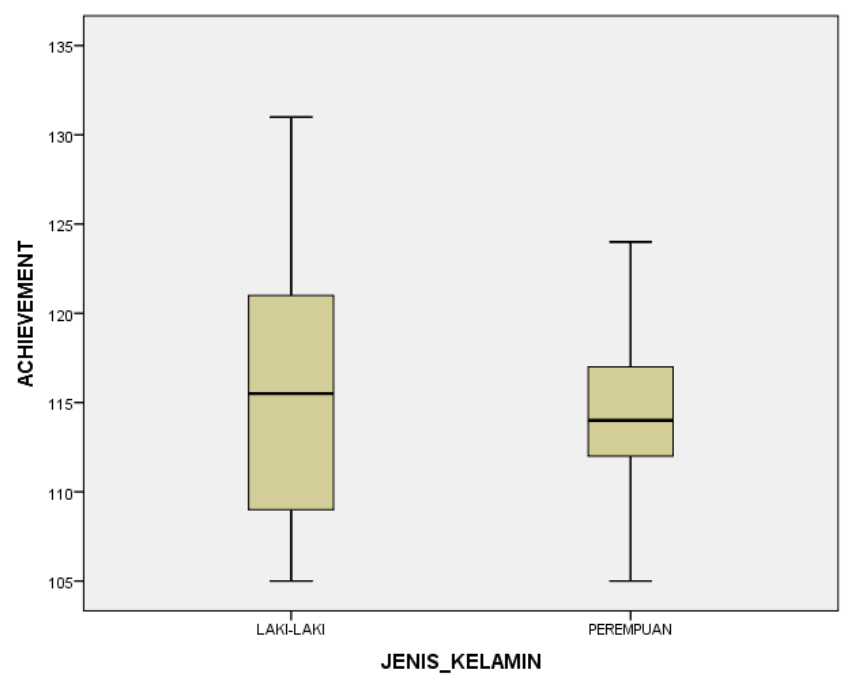

Gambar 2. Boxplots of Jenis Kelamin

Selanjutnya hasil pengujian interaksi konseling gestalt teknik permainan dialog dan teknik hipnokonseling dengan jenis kelamin terhadap self achievement diperoleh nilai signifikansi didapatkan pada Corrected Model yaitu pengaruh semua variabel independen dan interaksi teknik dengan jenis kelamin secara bersama-sama terhadap variabel dependen sebesar 0.092. . Jadi, simpulannya adalah tidak terdapat pengaruh interaksi konseling gestalt teknik permainan dialog dan teknik hipnokonseling dengan jenis kelamin terhadap self achievement.

Temuan berikutnya yaitu perbedaan self achievement antara siswa yang mengikuti konseling gestalt teknik permainan dialog dengan yang mengikuti teknik hipnokonseling pada siswa yang berjenis kelamin lakilaki. Berdasarkan uji Tukey diperoleh nilai Sig. sebesar 0,902 maka dapat ditarik kesimpulan bahwa "Tidak terdapat perbedaan self achievement antara siswa yang mengikuti konseling gestalt teknik permainan dialog dengan yang mengikuti teknik hipnokonseling pada siswa yang berjenis kelamin laki-laki. Dengan membandingkan rata-rata teknik permainan dialog dan teknik hipnokonseling, ternyata rata-rata teknik permainan dialog lebih rendah dari rata-rata teknik hipnokonseling. Berdasarkan kajian teoritik dari kedua teknik dari Konseling gestalt dan konsepsi tentang jenis kelamin, maka teknik hipnokonseling lebih sesuai diterapkan pada siswa berjenis kelamin laki-laki dibandingkan dengan teknik permainan dialog.

Temuan berikutnya yaitu perbedaan self achievement antara siswa yang mengikuti konseling gestalt teknik permainan dialog dengan yang mengikuti teknik hipnokonseling pada siswa yang berjenis kelamin perempuan. Berdasarkan uji Tukey diperoleh nilai Sig. sebesar 0,633 maka dapat disimpulkan bahwa "Tidak terdapat perbedaan secara signifikan self achievement antara siswa yang mengikuti konseling gestalt teknik permainan dialog dengan yang mengikuti teknik hipnokonseling pada siswa yang berjenis kelamin perempuan. Diketahui rata-rata teknik permainan dialog secara deskriptif lebih rendah daripada kelompok perempuan yang mengikuti konseling gestalt teknik hipnokonseling. Temuan selanjutnya yaitu perbedaan self achievement pada siswa yang mengikuti Konseling gestalt dengan teknik Permainan dialog dengan jenis kelamin. Berdasarkan uji Independent Samples Test diperoleh nilai Sig. (2-tailed) sebesar 0,457 maka dapat ditarik kesimpulan bahwa tidak terdapat perbedaan secara signifikan self achievement pada siswa yang mengikuti Konseling gestalt dengan teknik Permainan dialog ditinjau dari jenis kelamin.

Temuan selanjutnya yaitu perbedaan self achievement antara siswa yang mengikuti konseling gestalt teknik hipnokonseling dengan jenis kelamin. Berdasarkan uji Independent Samples Test di atas diperoleh nilai Sig. (2-tailed) sebesar 0,901 sehingga, dapat disimpulkan bahwa "Tidak terdapat perbedaan self achievement antara siswa yang mengikuti konseling gestalt dengan teknik hipnokonseling ditinjau dari jenis kelamin.

Penerapan konseling gestalt dengan menggunakan teknik permainan dialog dan teknik hipnokonseling menuntut konselor agar dapat merencanakan dan melaksanakan proses layanan bimbingan konseling secara lebih kreatif dan inovatif guna merangsang konseli lebih aktif dan terbuka menyampaikan dan menyelesaikan permasalahan yang dialami. 
Hasil penelitian menunjukkan bahwa self achievement siswa yang mengikuti teknik hipnokonseling lebih baik daripada siswa yang mengikuti permainan dialog. Berdasarkan pernyataan ini dapat kita katakan bahwa teknik hipnokonseling tepat diterapkan di sekolah. Penerapan teknik hipnokonseling berimplikasi terhadap perencanaan dan pengembangan model layanan bimbingan konseling dalam hal teknik dan prosedur kegiatan layanan yang diberikan kepada konseli.

Teknik hipnokonseling dapat digunakan sebagai salah satu alternatif teknik layanan bimbingan konseling yang dapat diterapkan sesuai dengan permasalahan dan karakteristik konseli. Kecenderungan individu, terutama pada masa remaja adalah pengelolaan diri sangatlah penting. Prosedur yang digunakan dalam teknik hipnokonseling telah disediakan dan dapat disesuaikan sesuai kebutuhan dan permasalahan konseli. Asumsi dasar dari teknik ini teknik ini bertujuan untuk membantu konseli dalam mengatur, memantau, dan mengevaluasi dirinya sendiri dalam mencapai perubahan tingkah laku ke arah yang lebih baik.

\section{Kesimpulan} berikut.

Berdasarkan hasil analisis data dan pembahasan hasil penelitian, maka dapat ditarik simpulan sebagai

1. Terdapat perbedaan self achievement antara siswa yang mengikuti konseling gestalt dengan teknik permainan dialog dengan yang mengikuti teknik hipnokonseling.

2. Tidak terdapat perbedaan self achievement ditinjau dari jenis kelamin.

3. Tidak terdapat pengaruh interaksi konseling gestalt teknik permainan dialog dan teknik hipnokonseling dengan jenis kelamin terhadap self achievement

4. Tidak terdapat perbedaan self achievement antara siswa yang mengikuti konseling gestalt dengan teknik permainan dialog dengan yang mengikuti teknik hipnokonseling pada siswa yang berjenis kelamin laki-laki

5. Tidak terdapat perbedaan self achievement antara siswa yang mengikuti konseling gestalt dengan teknik permainan dialog dengan yang mengikuti teknik hipnokonseling pada siswa yang berjenis kelamin perempuan

6. Tidak terdapat perbedaan self achievement siswa yang mengikuti konseling gestalt dengan teknik permainan dialog ditinjau dari jenis kelamin.

7. Tidak terdapat perbedaan self achievement siswa yang mengikuti konseling gestalt dengan teknik hipnokonseling ditinjau dari jenis kelamin.

\section{Referensi}

Afandi, R. (2012). Stage Hypnosis With Magic.Jakarta: PT Sarana Tutorial Nurani.

Ahmad, W., \& Chavan, B. S. (2017). Achievement Motivation among B. Ed. General and Special Education (MR) Teacher Trainees: A Comparison. Journal of Disability Management and Rehabilitation, 1(1), 13-16.

Azwar, S. (2005). Sikap Manusia: Teori dan Pengukurannya. Yogyakarta: Pustaka Pelajar.

Beisser, A. (1970). The paradoxical theory of change. Gestalt therapy now, 77-80.

Candiasa, M. (2011). Statistik Multivarian Disertai Aplikasi SPPS. Singaraja: UNDIKSHA Press.

Corey, G. (1988). Teori Dan Praktek Konseling Dan Psikoterapi.Jakarta: PT ERESCO.

Dantes, N. (2012). Metodologi Penelitian. Yogyakarta: Penerbit Andi.

Dharsana, K. (2010). Dasar-dasar BK Seri 2.Singaraja: BK FIP Undiksha.

(2013). Konseling Lintas Budaya. Singaraja: BK FIP Undiksha.

(2014). Model Teori Dan Teknik Untuk Penulisan Skripsi. Singaraja: BK FIP Undiksha 
- (2015). RPBK Seri Bimbingan Klasikal, Bimbingan Kelompok, Konseling Kelompok, Konseling Individu Untuk Pengembangan Self Achievement. Singaraja: BK FIP Undiksha.

. (2010). Teori-teori Konseling.Singaraja: BK FIP Undiksha.

(2012). Statistik Pendidikan.Singaraja: Pascasarjana Undiksha.

. (2013). Pengembangan Pribadi Konselor.Singaraja: BK FIP Undiksha.

(2013). Praktikum BK Karier. Singaraja: BK FIP Undiksha.

Dharsna, K. \& Suarni, K. (2016). Upaya Peningkatan Aktivitas Dan Hasil Belajar Dengan Model Pembelajaran Kooperatif Dengan Berbantuan Penilaian Portofolio Melalui Lesson Study Bermuatan Nilai Kearifan Lokal Dan Entrepreneurship Pada Mata Kuliah Praktikum Asesmen Psikologi Teknik Tes Di Semester VI Jurusan BK FIP Undiksha

Edgerton, J. D., \& Roberts, L. W. (2014). Need for Achievement. In Encyclopedia of Quality of Life and WellBeing Research (pp. 4284-4287). Springer Netherlands.

Ellias, J. (2009). Hipnosis dan Hipnoterapi Transpersonal/NLP. Yogyakarta: Pustaka Pelajar.

Fatchurrohman, R. (2017). Pengaruh motivasi berprestasi terhadap kesiapan belajar, pelaksanaan prakerin dan pencapaian kompetensi mata pelajaran produktif. Innovation of Vocational Technology Education, $7(2)$

Fisch, S., Brinkhaus, B., \& Teut, M. (2017). Hypnosis in patients with perceived stress-a systematic review. BMC Complementary and Alternative Medicine, 17(1), 323.

Gerungan. (1986). Psikologi Sosial. Bandung: Rosda Offset.

Gladding, S. (2012). Konseling Profesi Yang Menyeluruh. Jakarta: PT Indeks.

Gruber, N. (2017). Is the Achievement Motive Gender-Biased? The Validity of TAT/PSE in Women and Men. Frontiers in psychology, 8 .

Herawati, N. (2011). Pengaruh Metode Hypnoquantum Teaching terhadap Motivasi Belajar Mahasiswa. Pamator Journal, 4(1), 57-64.

Joseph, I. (2017). Factors Influencing International Student Entrepreneurial Intention in Malaysia. American Journal of Industrial and Business Management, 7(04), 424.

Kirchner, M. (2000). Gestalt therapy theory: An overview. Gestalt, 4(3), 4-3.

Menda, L. G. (2014). Penerapan Konseling Behavioral Dengan Teknik Modeling Untuk Meningkatkan Proaktif Siswa Kelas X BB SMA Negeri 2 Singaraja. Skripsi (tidak diterbitkan). Jurusan BK FIP Undiksha Singaraja.

Nurkancana, W. (1990). Evaluasi Hasil Belajar.Surabaya: Usaha Nasional.

Palmer, S. (2011). Konseling dan Psikoterapi. Yogyakarta: Pustaka Pelajar.

Prabowo. (2009). Hipnomedik, Hipnoterapi dan Hypnopregnancy. Yogyakarta: Nuh Medika.

Prayitno. (1994). Dasar-dasar Bimbingan dan Konseling. Jakarta: Direktorat Jendral Pendidikan Tinggi Departemen Pendidikan dan Kebudayaan.

Program P. U. S. (2015). Pedoman Penulisan Tesis. Singaraja: Undiksha.

Sardiman. (2008). Interaksi Dan Motivasi Dalam Belajar-Mengajar. Jakarta: PT Raja Grafindo. 
Sawni, A., \& Breuner, C. C. (2017). Clinical Hypnosis, an Effective Mind-Body Modality for Adolescents with Behavioral and Physical Complaints. Children, 4(4), 19.

Siagian, S. (2004). Teori Motivasi Dan Aplikasinya. Jakarta: PT Rineka Cipta.

Simanjuntak, N. (1952). Kamus Psikologi. Jakarta: Bina Aksara.

Steinmann, B. (2017). The role of the need for affiliation and the behavioral manifestation of implicit motives in effective leadership: a dimensional approach.

Sugiyono, D. (2000). Metode Penelitian. Bandung: CV Alvabeta.

Suranata, K. (2010). Panduan Memimpin Kelompok Dalam Konseling Kelompok. Singaraja: BK FIP Undiksha.

Suryabrata, S. (1986). Psikologi Pendidikan. Jakarta: Grafikatama.

Terhune, D. B., Cleeremans, A., Raz, A., \& Lynn, S. J. (2017). Hypnosis and top-down regulation of consciousness. Neuroscience \& Biobehavioral Reviews.

Uno, H. (2008). Teori Motivasi Dan Pengukurannya. Jakarta: PT Bumi Aksara.

Wood, P., Fox, A., Norton, J., \& Tas, M. (2017). The Experience of Lesson Study in the UK. In The Palgrave International Handbook of Action Research (pp. 203-220). Palgrave Macmillan US.

Yontef, G., \& Jacobs, L. (2010). 10 gestalt therapy. Current psychotherapies, 342.

Article Information (Supplementary)

\section{Conflict of Interest Disclosures:}

The authors declare that they have no significant competing financial, professional or personal interests that might have influenced the performance or presentation of the work described in this manuscript.

Copyrights Holder: Wayan Eka Paramartha, I Ketut Dharsana, Ni Ketut Suarni 2017

First Publication Right: BISMA The Journal of Counseling

https://doi.org/10.23887/128322017

Open Access Article | CC-BY Creative Commons Attribution 4.0 International License.

Word Count: 